\title{
Geochemistry and Origin of Banded Iron-Formation from the Granulitic Terrain of North Arcot District, Tamil Nadu, South India
}

\author{
K. S. S.PRASAD, D. B. SANKAR and Y.V. REDDY \\ Department of Geology, S. V. University, Tirupati, India \\ ksspsvu@gmail.com
}

Received 29 May 2012 / Accepted 15 June 2012

\begin{abstract}
Banded iron formations (BIF) form an important part of the Archean supracrustal belts of South India. Major, trace and rare earth elements (REE) chemistry of the banded iron formation of Kavuthimalai-Vediyappanmalai area, North Arcot district, Tamil Nadu region are utilized to compare with other world BIF and explore that this a separate type of Tamil Nadu type. The petrographic observation and the study of REE indicates that this BIF are derived from mantle through hydrothermal solutions and fumarolic activity in submarine conditions with an age of approximately $3800 \mathrm{~m}$.y. old.
\end{abstract}

Keywords: Banded iron formation (BIF), Rare earth elements (REE), Hydrothermal solutions, Granulite facies

\section{Introduction}

The strikingly banded rocks scattered across the upper Midwest and elsewhere throughout the world are actually ambassadors from the past, offering clues to the environment of the early earth more than 2 billion years ago. Called banded iron formations or BIFs, these ancient rocks formed between 3.8 and 1.7 billion years ago. The stripes represent alternating layers of silicarich quartz and iron-rich minerals like hematite and magnetite. In India, iron-formations were designated as "Banded Hematite Quartzite" and "Banded Magnetite Quartzite". Stratigraphic connotations like Iron Ore Series are given to these rocks in Bihar, Orissa, Andhra Pradesh and Tamil Nadu ${ }^{1-4}$. In other countries names like Taconote (Lake Superior), Itabirite (Brizil), Jaspilite (Australia) and Calico rock (South Africa) have been in use. Fermer subdivided the charnockite region of South India into Iron-Ore province and Magnese-Ore province- the Salem, Arcot and Madras provinces of Tamil Nadu and Prakasam province of Andhra Pradesh were included in the Iron-Ore province and the rest comes under Manganese-Ore province.

The Banded Iron Formations occur in high grade granulite terrain and greenstone terrain of South India in the states of Karnataka, Kerala, Tamil Nadu and Andhra Pradesh. The BIF of Arcot district of Tamil Nadu are associated with Pyroxene granulites, charnockites and granite gneisses. The area under study, being a part of North Arcot district comes under Iron-Ore province, since it includes iron ore as one of the rock types. 


\section{Geological background of the area}

The area under study forms the part of granulitic terrain of South India. It lies between $12^{\circ}$ $15^{\prime}-12^{\circ} 19^{\prime}$ North latitudes and $78^{\circ} 58^{\prime}-79^{\circ} 05^{\prime}$ East longitudes around KavuthimalaiVediyappanmalai area, North Arcot district, Tamil Nadu. In this area pyroxene granulites, charnockites, granite gneisses and Banded Iron Formations (BIFs) are present according to their order of superposition. The pyroxene granulites, charnockites and granite gneisses show sharp contacts with one another. The charnockites have xenoliths of pyroxene granulites, which indicates the former as younger. Finally the BIFs deposited after the fault zone was taken place in NE-SW direction and later metamorphosed (Figure 1).

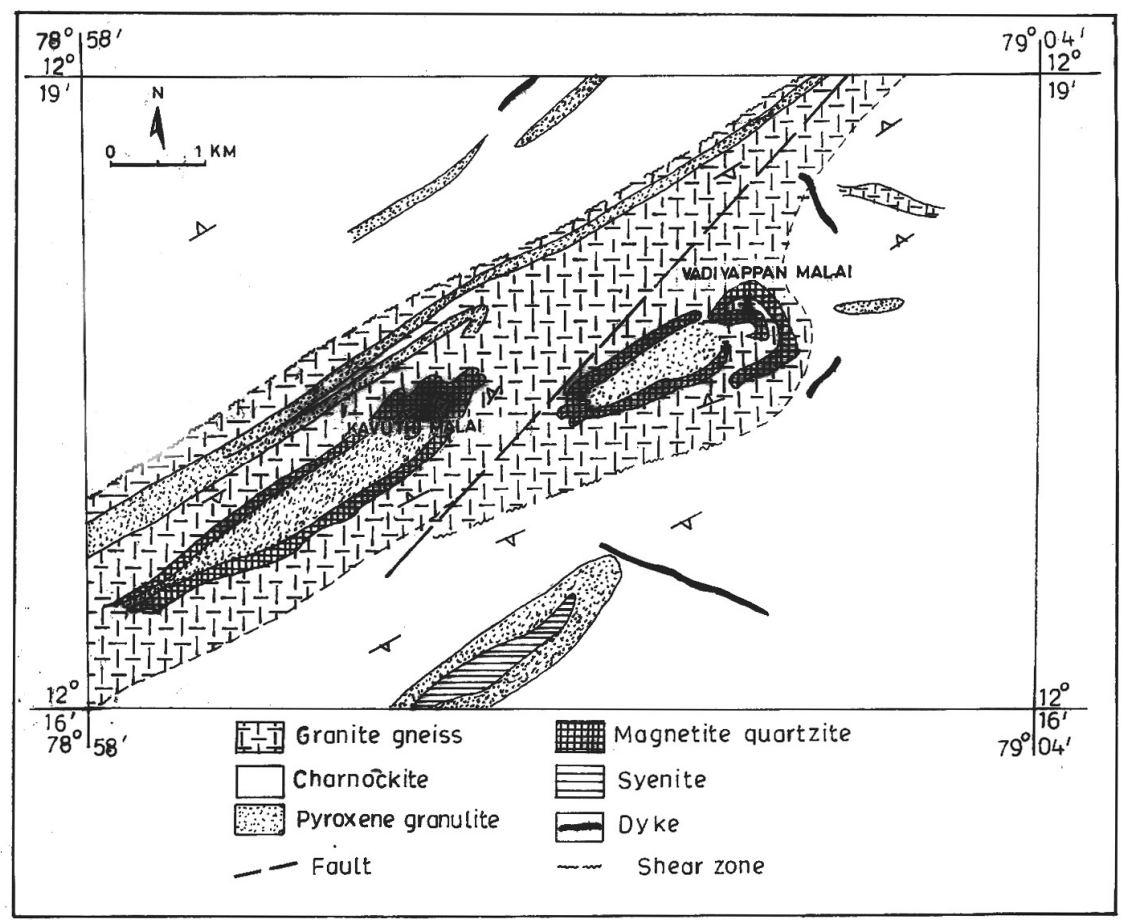

Figure 1. Geological map of the study area

The BIFs in the western portion of the fault occur as steeply dipping on the top as basinlike structure. On the Eastern end of this hill the BIFs on the Northern flank is repeatedly folded and is connected with the Southern flank at a point near the peak of the hill. The rocks show distinct banding, due to the occurrence of thin discontinuous ribbons and laminae of quartz alternating with those rich in dark iron minerals. The BIFs are wellbanded rocks consisting of millimeter to centimeter thick alternating iron-rich and silica-rich layers. The ore in the northern limb is medium to coarse grained, while in the southern limb it is usually medium grained. In places, especially in the eastern region of the hill magnetite patches are very coarse grained, with well developed crystals.

\section{Petrography}

The petrogrphically the BIFs composed of Magnetite and quartz with minor proportions of hypersthenes, hedenbergite, commingtonite/grunerite, garnet and apatite are noticed in these rock formations. Magnetite occurs as irregular grains or bands. The association of magnetite 
with quartz ranges from granular to well banded nature with alternate layers of quartz and magnetite. Numerous cracks in quartz filled with iron oxide are present. In some cases the veins appear to be feeding the iron oxide bands. In some sections fine hair like cracks from the iron oxide grains extends in to quartz grins, which form a mesh like network.

Under reflected light magnetite is grey in colour with brownish tinge. The octahedral and cubic parting planes are noticed. The cubic nature of parting planes indicated by triangular pits. In some samples magnetite shows faint anisotropism due to the presence of martite formed by martitistion, along the octahedral parting planes and thus giving rise to a network of triangular lattice pattern. Martite is identified by its high reflectance than magnetite and by its light grey in color with bluish tinge.

Quartz is the dominant mineral in many assemblages. It occurs as elongated grains and alternate bands with magnetite. This mineral is also occurs as inclusions in magnetite. The grain size is observed to be finer at the contact with magnetite than far off. The deformation effects in quartz are marked by marginal granulation and development of numerous cracks filled with iron oxide. The individual grains of quartz contain dust like numerous inclusions of magnetite.

\section{Sampling and analytical techniques}

Proper care was taken to collect the best possible fresh sample. Samples with mesoband thicknesses below $3 \mathrm{~mm}$ were selected for major and trace elemental analysis. The major elements and trace elements were determined by x-ray fluorescence method in the laboratory of the Atomic Mineral Division, Hyderabad. Rare Earth Elements (REE) were determined by Instrumental Neutron Activation Analysis (INAA) at the Department of Earth

Sciences, University of Lowell, Massachusetts, USA. The standards were checked against the standards of BRC-1 and AUG-1. Reproducibility and estimated analytical errors were less than $5 \%$ for major and trace elements.

\section{Results and Discussion}

\section{Geochemistry of banded iron formations}

Major element chemistry of the ten representative BIF samples is shown in Table $1 . \mathrm{SiO}_{2}$ and $\mathrm{Fe}_{2} \mathrm{O}_{3}$ constitute nearly $96 \%$ to $99 \%$ of the bulk of the banded iron -formations. $\mathrm{SiO}_{2}$ and $\mathrm{Fe}_{2} \mathrm{O}_{3}$ content of the studied banded iron-formations have an inverse relationship to each other. $\mathrm{Al}_{2} \mathrm{O}_{3}$ content varies between 0.10 and $0.63 \% . \mathrm{Na}_{2} \mathrm{O}$ and $\mathrm{K}_{2} \mathrm{O}$ content are very low in the studied samples. $\mathrm{P}_{2} \mathrm{O}_{5}$ content in the banded iron-formations ranges between 0.15 and $0.43 \%$. $\mathrm{MnO}$ content ranges between 0.1 and $0.3 \%$. $\mathrm{MgO}(0.52-2.00 \%)$ and $\mathrm{CaO}(0.23-$ $1.25 \%$ ) contents are significantly very low.

The average composition of BIF of the study area is compared with average chemical compositions of BIF of different areas of the world are shown in Table 2. When the average values of the Archaean, Proterozoic, Suoperior, Algoma, Orissa and study area are plotted against the respective oxide percentages (Figure 2), it is observed that there is a significant variation in $\mathrm{Fe}_{2} \mathrm{O}_{3}$ and $\mathrm{P}_{2} \mathrm{O}_{5}$ proportions which are high in the study area $\mathrm{BIFs}$, where as $\mathrm{Al}_{2} \mathrm{O}_{3}$ and $\mathrm{CaO}$ are in much lower proportion. The average proportions of $\mathrm{MgO}$ and $\mathrm{K}_{2} \mathrm{O}$ of study area show similarity with $\mathrm{MgO}$ and $\mathrm{K}_{2} \mathrm{O}$ of Superior oxide facies, but it differs from Algoma oxide facies. $\mathrm{MnO}(0.23)$ of the study area is similar to the Algoma oxide facies (0.22). $\mathrm{Na}_{2} \mathrm{O}(0.23)$ is similar to the Archaean and Proterozoic BIF proportions of 0.22 and 0.29 respectively, but it is lower to the Algoma type $\mathrm{BIF}(0.31)$ and higher to that of Superior type (0.12). 
Table 1. Chemical composition of BIF of the study area

\begin{tabular}{|c|c|c|c|c|c|c|c|c|c|c|c|}
\hline & $1 / \mathrm{K} 85$ & $2 / \mathrm{V} 74$ & $3 / \mathrm{K} 89$ & 4/V72 & $5 / \mathrm{K} 16$ & $6 / \mathrm{V} 65$ & 7/K79 & 8/V59 & 9/V87 & $10 / \mathrm{K} 90$ & erage \\
\hline & \multicolumn{11}{|c|}{ Major Elements (wt\%) } \\
\hline $\mathrm{SiO}_{2}$ & 47.55 & 43.65 & 48.10 & 39.20 & 47.20 & 41.10 & 46.00 & 42.51 & 46.10 & 44.89 & 44.62 \\
\hline $\mathrm{TiO}_{2}$ & 0.32 & 0.23 & 0.25 & 0.35 & 0.48 & 0.10 & 0.20 & 0.33 & 0.20 & 0.40 & 0.22 \\
\hline $\mathrm{Al}_{2} \mathrm{O}_{3}$ & 0.10 & 0.35 & 0.63 & 0.56 & 0.30 & 0.32 & 0.33 & 0.35 & 0.15 & 0.36 & 0.35 \\
\hline $\mathrm{Fe}_{2} \mathrm{O}_{3}$ & 49.07 & 54077 & 49.72 & 56.90 & 50.48 & 57.28 & 50.75 & 56.44 & 51.45 & 53.14 & 53.00 \\
\hline $\mathrm{MgO}$ & 1.00 & 1.45 & 1.15 & 2.00 & 1.05 & 0.52 & 1.50 & 0.75 & 1.45 & 0.25 & 1.21 \\
\hline $\mathrm{CaO}$ & 0.85 & 1.25 & 0.30 & 0.23 & 0.50 & 0.35 & 1.22 & 0.43 & 1.24 & 0.63 & 0.70 \\
\hline $\mathrm{Na} 2 \mathrm{O}$ & 0.15 & 0.18 & 0.22 & 0.65 & 0.19 & 0.15 & 0.17 & 0.22 & 0.10 & 0.30 & 0.23 \\
\hline $\mathrm{K} 2 \mathrm{O}$ & 0.10 & 0.17 & 0.20 & 0.15 & 0.15 & 0.40 & 0.10 & 0.13 & 0.10 & --- & 0.17 \\
\hline $\mathrm{MnO}$ & 0.20 & 0.24 & 0.23 & 0.22 & 0.30 & 0.22 & 0.21 & 0.10 & 0.28 & 0.25 & 0.23 \\
\hline $\mathrm{P}_{2} \mathrm{O}_{5}$ & 0.28 & 0.15 & 0.39 & 0.43 & 0.27 & 0.15 & 0.35 & 0.28 & 0.29 & 0.20 & 0.28 \\
\hline $\mathrm{CaO} / \mathrm{MgO}$ & 0.85 & 0.86 & 0.26 & 0.12 & 0.47 & 0.67 & 0.78 & 0.58 & 0.84 & 0.51 & 0.60 \\
\hline \multirow[t]{2}{*}{$\mathrm{Mn} / \mathrm{Fe}$} & 0.03 & 0.02 & 0.03 & 0.02 & 0.03 & 0.02 & 0.03 & 0.07 & 0.03 & 0.02 & 0.03 \\
\hline & \multicolumn{11}{|c|}{ Trace Elements (ppm) } \\
\hline Co & 6.00 & --- & 8.00 & --- & 10.00 & --- & --- & --- & 5.00 & --- & 7.00 \\
\hline $\mathrm{Cr}$ & 85.00 & 156.00 & 81.00 & 120.00 & 102.00 & 143.00 & 75.00 & 94.00 & 98.00 & 135.00 & 109.00 \\
\hline $\mathrm{Ni}$ & 15.00 & 22.00 & 19.00 & 26.00 & 17.00 & 28.00 & 16.00 & 23.00 & 12.00 & 25.00 & 21.00 \\
\hline V & 38.00 & 42.00 & 23.00 & 56.00 & 26.00 & 43.00 & 20.00 & 32.00 & 39.00 & 31.00 & 35.00 \\
\hline $\mathrm{Cu}$ & 16.00 & 28.00 & 14.00 & 19.00 & 32.00 & 19.00 & 25.00 & 30.00 & 26.00 & 23.00 & 23.00 \\
\hline $\mathrm{Ba}$ & 28.00 & 22.00 & 16.00 & 13.00 & 18.00 & 30.00 & 21.00 & 19.00 & 40.00 & 26.00 & 23.00 \\
\hline $\mathrm{Sr}$ & 16.00 & 24.00 & 13.00 & 10.00 & 6.00 & 19.00 & 8.00 & 26.00 & 12.00 & 18.00 & 15.00 \\
\hline $\mathrm{Co} / \mathrm{Ni}$ & 0.40 & --- & 0.42 & --- & 0.59 & --- & --- & --- & 0.41 & --- & 0.46 \\
\hline
\end{tabular}

Table 2. Comparison of the study area major element (wt $\%$ ) with other BIF types areas of the world

\begin{tabular}{ccccccc}
\hline Constituents & 1 & 2 & 3 & 4 & 5 & 6 \\
\hline $\mathrm{SiO}_{2}$ & 50.50 & 47.20 & 47.30 & 46.90 & 47.02 & 44.62 \\
$\mathrm{Al}_{2} \mathrm{O}_{3}$ & 3.00 & 1.39 & 1.25 & 1.15 & 0.70 & 0.35 \\
$\mathrm{Fe}_{2} \mathrm{O}_{3}$ & 41.33 & 44.51 & 45.79 & 43.76 & 53.33 & 53.21 \\
$\mathrm{MgO}$ & 1.53 & 1.24 & 3.66 & 4.41 & 0.13 & 1.21 \\
$\mathrm{CaO}$ & 1.51 & 1.58 & 2.84 & 4.43 & 0.17 & 0.70 \\
$\mathrm{MnO}$ & 0.22 & 0.73 & 0.59 & 0.59 & 0.06 & 0.23 \\
$\mathrm{Na} 2 \mathrm{O}$ & 0.31 & 0.12 & 0.22 & 0.29 & 0.10 & 0.23 \\
$\mathrm{~K}_{2} \mathrm{O}$ & 0.58 & 0.14 & 0.09 & 0.48 & 0.13 & 0.17 \\
$\mathrm{P}_{2} \mathrm{O}_{5}$ & 0.21 & 0.06 & 0.22 & 0.14 & 0.07 & 0.28 \\
\hline
\end{tabular}

1-Average Algoma-type oxide facies ${ }^{5}$, 2-Average Lake Superior-type ${ }^{5}$, 3-Average Archean BIF ${ }^{6}$, 4-Average Proterozoic BIF ${ }^{7}$, 5-Average of Orissa BIF ${ }^{8}$, 6-Average of the study area BIF 


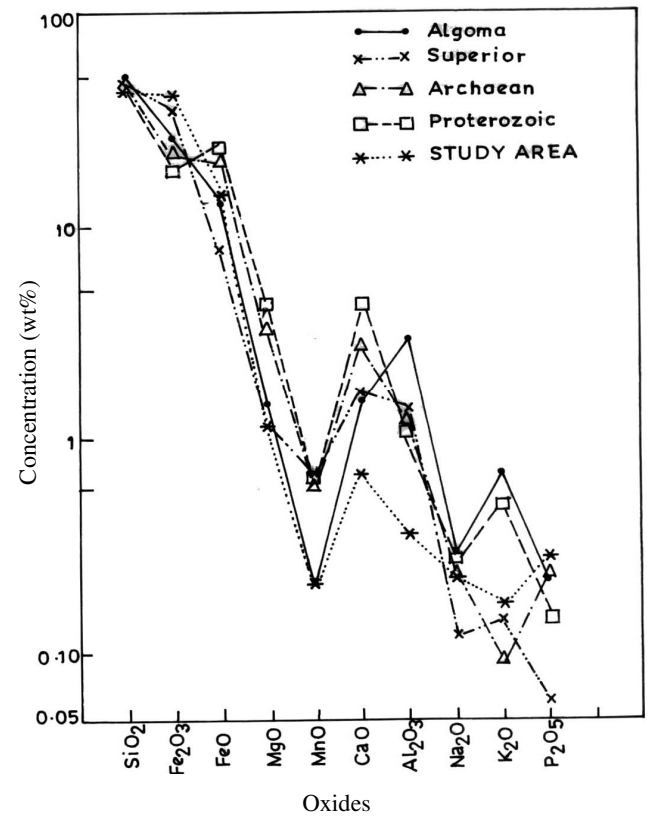

Figure 2. Variation in chemical composition of the study area and other world BIF

The REE content of the selected samples of BIF are estimated and presented in Table 3, and chondrite normalized REE patterns are shown in Figure 3. The average REE content compared with other BIF of world is given in Table 4 and in Figure 4. The low REE concentrations of BIF of the study area are consistent with the REE data of Archaean ironformations elsewhere ${ }^{8}$. The chondrite normalized REE patterns of the study area are similar to those reported from BIF of Isua of Green land ${ }^{8,9}$, sargur supracrustals of South India.

Table 3. The REE concentration (in ppm) of BIF

\begin{tabular}{cccccccc}
\hline $\mathrm{REE}$ & 1/V72 & 2/V74 & 3/V59 & $4 / \mathrm{K} 79$ & $5 / \mathrm{K} 16$ & $6 / \mathrm{K} 90$ & Average \\
\hline $\mathrm{La}$ & 2.41 & 2.60 & 3.80 & 3.40 & 4.93 & 2.40 & 3.36 \\
$\mathrm{Ce}$ & 3.39 & 8.70 & 7.00 & 6.40 & 9.61 & 5.90 & 6.83 \\
$\mathrm{Nd}$ & 1.81 & 5.00 & 3.80 & 2.90 & 5.43 & 4.30 & 3.87 \\
$\mathrm{Sm}$ & 0.59 & 0.53 & 1.40 & 0.62 & 1.26 & 0.74 & 0.86 \\
$\mathrm{Eu}$ & 0.35 & 0.35 & 0.72 & 0.42 & 0.89 & 0.50 & 0.54 \\
$\mathrm{~Tb}$ & 0.16 & 0.10 & 0.27 & 0.18 & 0.21 & 0.37 & 0.22 \\
$\mathrm{Ho}$ & 0.15 & --- & -- & 0.24 & 0.25 & 0.51 & 0.19 \\
$\mathrm{Yb}$ & 0.45 & 0.35 & 0.96 & 0.57 & 0.68 & 1.10 & 0.69 \\
$\mathrm{Lu}$ & 0.09 & 0.06 & 0.19 & 0.13 & 0.14 & 0.21 & 0.14 \\
$\mathrm{LREE}$ & 8.55 & 17.18 & 16.72 & 13.74 & 22.12 & 13.84 & 15.36 \\
$\mathrm{HREE}$ & 0.85 & 0.51 & 1.42 & 1.12 & 1.28 & 2.19 & 1.24 \\
$\mathrm{LREE}$ & 9.40 & 17069 & 18.14 & 14.86 & 23.40 & 16.03 & 16.60 \\
$\mathrm{La} / \mathrm{Lu}$ & 26.78 & 43.33 & 20.00 & 26.15 & 35.21 & 11.42 & 23.29 \\
$\mathrm{Nd} / \mathrm{Yb}$ & 4.02 & 14.20 & 3.96 & 5.09 & 7.99 & 3.91 & 5.60 \\
$\mathrm{Eu} / \mathrm{Sm}$ & 0.59 & 0.66 & 0.51 & 0.68 & 0.71 & 0.68 & 0.63 \\
$\mathrm{LaN} / \mathrm{YbN}$ & 3.61 & 5.02 & 2.67 & 4.04 & 4.91 & 1.47 & 3.62 \\
$\mathrm{LREE} / \mathrm{HREE}$ & 10.06 & 33.69 & 11.71 & 12.27 & 17.28 & 6.32 & 12.39 \\
\hline
\end{tabular}




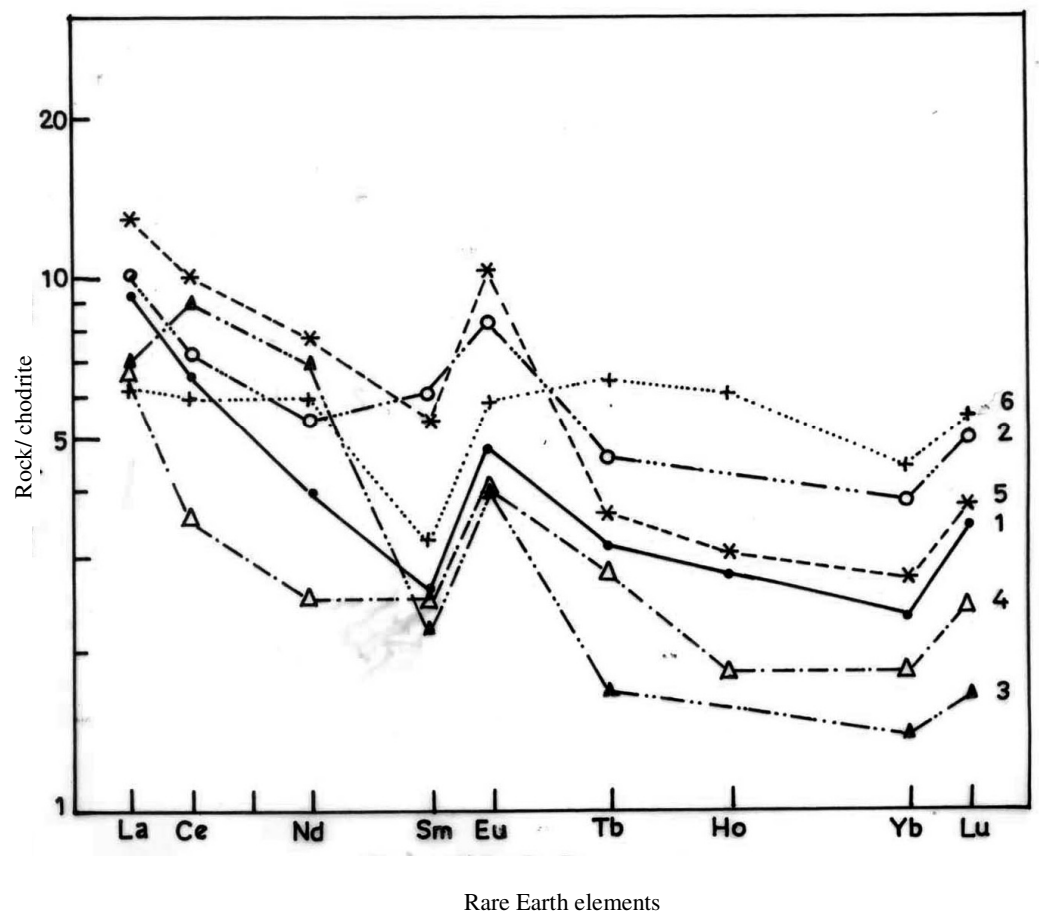

Figure 3. Chondrite normalized REE abundance of the study area

Table 4. Comparison of the study area REE content (in ppm) with other BIF types

\begin{tabular}{ccccccc}
\hline REE content & 1 & 2 & 3 & 4 & 5 & 6 \\
\hline $\mathrm{La}$ & 3.930 & 2.260 & 2.720 & 2.310 & 1.850 & 30260 \\
$\mathrm{Ce}$ & 6.170 & 3.700 & 4.520 & 6.300 & 6.700 & 6.830 \\
$\mathrm{Nd}$ & 3.660 & 1.990 & 2.370 & 4.700 & --- & 3.870 \\
$\mathrm{Sm}$ & 0.599 & 0.359 & 0.434 & 0.570 & 0.437 & 0.860 \\
$\mathrm{Eu}$ & 0.389 & 0.202 & 1.151 & 0.580 & 0.187 & 0.540 \\
$\mathrm{~Tb}$ & --- & --- & --- & --- & 0.132 & 0.220 \\
$\mathrm{Ho}$ & 0.191 & 0.116 & --- & 0.460 & --- & 0.190 \\
$\mathrm{Yb}$ & 0.622 & 0.380 & 0.242 & 1.570 & 0.850 & 0.690 \\
$\mathrm{Lu}$ & 0.106 & 0.067 & 0.032 & 0.200 & 0.138 & 0.140 \\
LRE & 15.620 & 9.074 & 10.460 & 16.620 & 10.290 & 16.600 \\
Eu/Sm & 0.640 & 0.560 & 0.340 & 1.010 & 0.427 & 0.630 \\
La/Yb & 6.320 & 5.940 & 11.230 & 1.350 & 2.176 & 4.720 \\
\hline 1-Massive magnetite, Buffin Island; 2- Average Archean oxide facies Iron-Formation, \\
3-Average Sokoman oxide facies, Labrador; 4- Sedimentary magnetites from the Orissa; \\
5-Averageof Sargur BIF ; 6- Average of the present area BIF
\end{tabular}




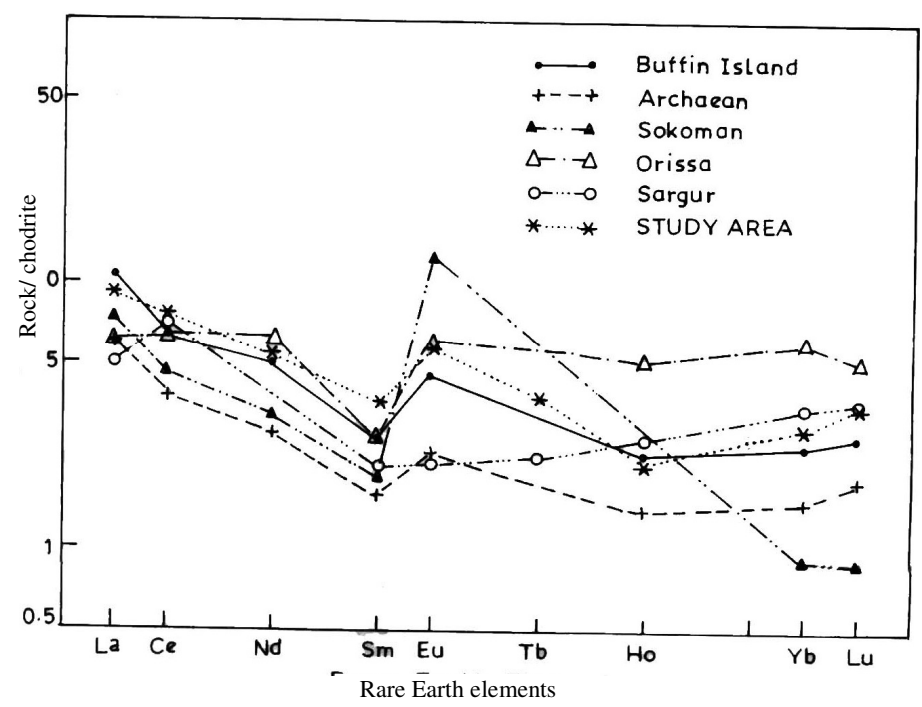

Figure 4. Chondrite normalized REE abundance of the study area and other world BIF

$\mathrm{BIF}$ has been reported from different parts of the world and the source of $\mathrm{Fe}$ and $\mathrm{Si}$ within $\mathrm{BIF}$ is an intriguing problem ${ }^{10,11}$. Mid-oceanic ridge or hot spot style tectonic setting are likely settings from where iron could have released during these tectonic activities ${ }^{12,13}$. The several giant and world class ore systems were formed during intra-plate tectanothermal and rifting events ${ }^{14}$. Iron was scavenged from the early Achaean oceanic crust and re-deposited on the ocean floor by hydrothermal fluids aiding the deposition of BIFs ${ }^{15}$. It is difficult to attribute a single depositional model for the formation of BIFs and the reason for lack of uniform genetic model may be attributed to their formation at long span of depositional episodes during Precambrian time.

The banded iron formations and associated rocks of the study area had undergone granulite facies of metamorphism ${ }^{16}$. To decipher the nature of original material is not so easy; more so when materials of similar composition may be formed by diverse processes and also any attempt to understand the origin must be based on features on them due to metamorphism, as the granulite facies conditions obliterates the original structures.

In the petrographical study it was found that magnetite occurs in the form of veins filling up the cracks, which seem as feeders to the concentrated bands. The veins are more or less perpendicular to the bands and the presence of closely spaced fractures cutting across the quartz grains indicates that the rocks were subjected to deformational forces. It is possible that the iron oxide which was mobilized during metamorphism moved into these cracks, fractures and granulated regions, thus occupying the areas of low pressure.

Normalized REE patterns show general paucity of REE, relative enrichment of LREE over HREE, positive Eu anomalies, low proportions of $\mathrm{Ce}, \mathrm{Sm}, \mathrm{Lu}$ and $\mathrm{La} / \mathrm{Lu}$ ratio suggests that the study area BIFs are Archaean sedimentary in nature ${ }^{16-19}$ Manikyamba et al. ${ }^{20}$ suggested that La enrichment, positive $\mathrm{Eu}$ and low proportions of $\mathrm{Ce}$ and $\mathrm{Sm}$ in BIF of Sandur Schist Belt indicates that the iron formations received their constituents from hydrothermal solutions derived from mantle along with the associated basic volcanism. Khan et al. ${ }^{21}$ suggested that the REE, iron and silica of BIF are derived from mantle through hydrothermal solutions. 
The low proportions of $\mathrm{Ce}$ and $\mathrm{Sm}$ in BIF of the study area may be due to differentiation during digenetic changes and metamorphism ${ }^{24,25}$. Most of the Archaean iron-formations are characterized by relative enrichment of Eu compared to the other REE, where as Eu abundance is in Proterozoic iron-formations. Relative enrichment of $\mathrm{Eu}$ in Sargur BIF substantiates the above view of enrichment of Eu in Archean BIF. Eu anomalies in iron-formations have been used as indicators of oxidizing and reducing conditions in the Precambrian atmosphere ${ }^{6,26}$. Presence of Eu anomaly in the study area BIF indicates prevalence of oxidising environment at the time of deposition during Archaen times ${ }^{8}$. Hydrothermal solutions extremely depleted with REE, but show positive $\mathrm{Eu}$ anomaly and $\mathrm{La}$ enrichment ${ }^{27}$. The relationship between $\sum(\mathrm{Co}+\mathrm{Cu}+\mathrm{Ni})$ and $\sum$ REE of hydrothermal and hydrogenous deposits are used by Dymek and Klein ${ }^{28}$ Klein and Beukes ${ }^{29}$ to reconstruct the fields of hydrothermal and hydrogenous deposits (Figure 5). All the samples of the study area BIFs fall within the field of hydrothermal deposits, which also suggest that the major part of the iron in the studied banded iron formations were added to the bottom sea water by hydrothermal solutions derived from hydrothermally active marine environments. However it is confirmed that the La enrichment, depletion of total $\mathrm{REE}$, positive $\mathrm{Eu}$ anomaly, $\mathrm{Nd} / \mathrm{Yb}, \mathrm{La} / \mathrm{Lu}$ and LREE/HREE ratios of BIFs of the study area indicate that iron silica and REE were supplied by hydrothermal and fumarolic activity accompanying submarine environment.

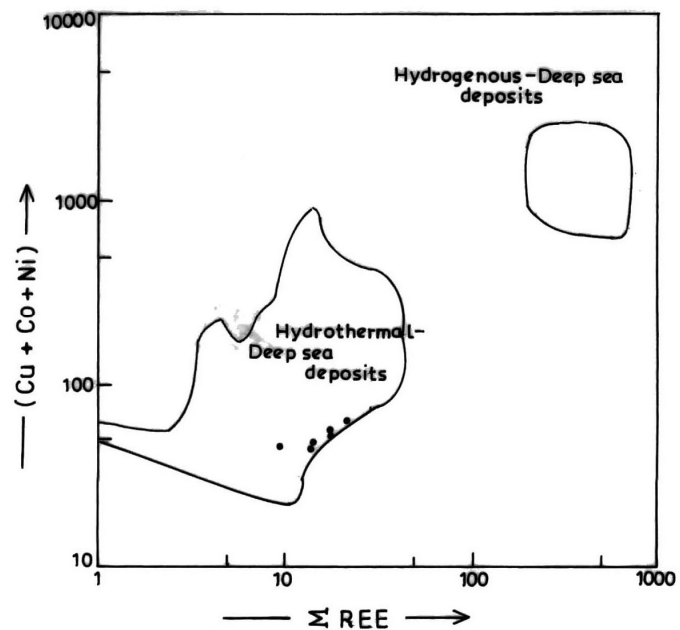

Figure 5. $(\mathrm{Cu}+\mathrm{Co}+\mathrm{Ni})$ vs. REE plot showing the hydrothermal source of REE and other constituents for BIF of the study area.

In view of the above observations of ferried elemental, major elemental distribution, presence of vein connections in the magnetite grains and bands, the association of metavolcanics, presence of good banding, granulite texture, their association with commingtonite/grunerite it is concluded that magnetite-quartzites are meta-sediments, which may be formed originally through hydrothermal and later metamorphosed.

The average analysis of the BIF of the study area compared with those of Algoma, Superior and Sargur BIF (T.N. Type), is given the Table 5. The major elemental concentrations of the study area differ markedly from those of the Algoma and Superior types viz., $\mathrm{SiO}_{2}$, $\mathrm{Al}_{2} \mathrm{O}_{3}, \mathrm{CaO}, \mathrm{MgO}$ and $\mathrm{MnO}$ values are relatively low and $\mathrm{FeO}$ content is high. It is observed that the absence of $\mathrm{CO}_{2}$ and $\mathrm{S}$, the study area is akin to Tamil Nadu type of Sargur area. 
Table 5. Comparison of the study area BIF major elements (Wt\%) with other world BIF types

\begin{tabular}{ccccc}
\hline Constituents & Algoma 1 & Superior 2 & T.N type 3 & Study area 4 \\
\hline $\mathrm{SiO}_{2}$ & 50.50 & 47.20 & 49.16 & 44.62 \\
$\mathrm{Al}_{2} \mathrm{O}_{3}$ & 0.300 & 1.39 & 0.97 & 0.35 \\
$\mathrm{FeO}^{\mathrm{t}}$ & 37.21 & 40.06 & 42.60 & 47.87 \\
$\mathrm{MgO}$ & 1.53 & 1.23 & 1.59 & 1.21 \\
$\mathrm{CaO}$ & 1.51 & 1.58 & 1.59 & 1.79 \\
$\mathrm{Na}_{2} \mathrm{O}$ & 0.31 & 0.12 & 0.10 & 0.23 \\
$\mathrm{~K}_{2} \mathrm{O}$ & 0.58 & 0.14 & 0.71 & 0.17 \\
$\mathrm{MnO}$ & 0.22 & 0.73 & 0.19 & 0.21 \\
$\mathrm{P}_{2} \mathrm{O}_{5}$ & 0.21 & 0.06 & 0.05 & 0.20 \\
$\mathrm{CO}_{2}$ & 0.29 & 0.02 & --- & --- \\
\hline
\end{tabular}

\section{Origin}

Meta-sedimentary origin was advocated, by many workers ${ }^{26}$ for the magnetite-quartzite of Tamil Nadu and Iron ores of South India. The magnetite-quartzite which are of sedimentary origin may be originally formed in the form of a residual deposit, chemical precipitate, biogenic formation, volcano sedimentary or hydrothermal in nature.

In the petrographical study it was found that magnetite occurs in the form of veins filling up the cracks, which seem as feeders to the concentrated bands. The veins are more or less perpendicular to the bands and the presence of closely spaced fractures cutting across the quartz grains indicates that the rocks were subjected to deformational forces. It is possible that the iron oxide which was mobilized during metamorphism moved into these cracks, fractures and granulated regions, thus occupying the areas of low pressure.

Ramberg ${ }^{27}$, Turner and Verhoogen ${ }^{28}$ believed that the process operating within a rock leading to the formation of layers of contrasting mineralogy constitute the metamorphic differentiation. If the original material that produced the magnetite-quartzite consists of both silica and iron oxide, it is probable that the iron oxide is segregated into bands moving along the cracks and fractures during deformation. In this process the iron oxide which was originally present, possibly in a dispersed form has to be concentrated into bands by drawing the material from external source of fractures even in the granulite facies metamorphism and the structures of veins connecting the bands in the magnetite-quartzite show that the iron oxide has migrated into the rock from somewhere any they do not show any evidence of obtaining the material within the rock.

The magnetite quartzite of the study area show low concentration of $\mathrm{Al}_{2} \mathrm{O}_{3}, \mathrm{CaO}$ and $\mathrm{MnO}$, which infers the non-volcanogenic origin Very low concentrations of $\mathrm{Na}_{2} \mathrm{O}$ and $\mathrm{K}_{2} \mathrm{O}$ values also substantiate the above observation ${ }^{29}$. Paucity of REE, relative enrichment of LREE over HREE, La enrichment, positive $\mathrm{Eu}$ and low proportions of $\mathrm{Ce}$ and $\mathrm{Sm}$ of this study area indicates that the iron silica and REE of BIF are derived from mantle through hydrothermal solutions and fumarolic activitiy in submarine conditions. The same opinion was expressed by Manikyamba et $\mathrm{l}^{20}$.

In view of the above observations of ferried elemental, major elemental distribution, presence of vein connections in the magnetite grains and bands, the association of meta- 
volcanics, presence of good banding, granulite texture, their association with commingtonite/grunerite it is concluded that magnetite-quartzites are meta-sediments, which may be formed originally through hydrothermal and later metamorphosed.

Holland ${ }^{10}$ has postulated upwelling of deep ocean water as an alternative source of iron in iron formations, Windley et al., ${ }^{30}$ and Grass ${ }^{31}$ consider these alternative mode of transport of iron from a submarine hydrothermal source to a zone of precipitation as the dominant process in the deposition of iron formations.

Age

Several workers have given the ages of different horizons based on mineralogy, geochronology and chemical analysis. Jayaram et al. $^{32}$ inferred that the iron formations of Southern Karnataka belongs to Precambrian age and the they may be as old as 3,600 m.y, on the basis of geological association and geochronological data of the associated rocks such as cordiorite and charnockites. The ages of the oldest gneisses of granulite facies from south India $^{33}$ and for the charnockites of Tamil $\mathrm{Nadu}^{34}$ are $3065 \pm$ and 2900 to 3200 respectively. Lepp and Goldich ${ }^{35}$ have compared the age of various iron formations on the basis of major elements as given in the Table 6 .

Table 6. Comparison of chemical analysis of study area BIF with precambrian and postprecambrian BIF formation

\begin{tabular}{cccc}
\hline Constituent & Precambrian & Post-precambrian & Present study area \\
\hline $\mathrm{SiO}_{2}$ & 42.90 & 12.90 & 44.62 \\
$\mathrm{Al}_{2} \mathrm{O}_{3}$ & 1.60 & 6.10 & 0.35 \\
$\mathrm{CaO}$ & 1.50 & 14.30 & 1.70 \\
$\mathrm{MgO}$ & 2.80 & 2.90 & 1.20 \\
$\mathrm{MnO}$ & 1.00 & 0.34 & 0.23 \\
$\mathrm{P}_{2} \mathrm{O}_{5}$ & 0.26 & 0.86 & 0.28 \\
$\mathrm{TiO}_{2}$ & 0.15 & 0.45 & 0.22 \\
$\mathrm{Mn} / \mathrm{Fe}$ & 0.028 & 0.009 & 0.028 \\
$\mathrm{CaO} / \mathrm{MgO}$ & 0.590 & 8.800 & 0.595 \\
\hline
\end{tabular}

From the major elemental concentration it is noticed that: Precambrian iron formations are characterized by their high content of silica, the average content of $\mathrm{SiO} 2 \mathrm{is} 43 \%$ and for the younger formations it is $13 \%$. The study area has an average of $44.62 \%$. The average $\mathrm{Al}_{2} \mathrm{O}_{3}$ content of precambrian iron formations is $1.6 \%$, whereas that of post-cambrians is $6.1 \%$ and study area is having a value of $0.35 \%$.

The most striking difference between Precambrian and post-cambrian can very well be computed by the $\mathrm{CaO}$ content i.e. $1.5 \%$ and $14 \%$ respectively. The average $\mathrm{CaO}$ content of the study area is $0.70 \%$. The average value of $\mathrm{CaO} / \mathrm{MgO}$ ratio for Precambrian and postcambrian and present area are $0.590,8.0$ and 0.595 respectively, which conforms that the study area BIF is similar to precambrians.

The $\mathrm{P}_{2} \mathrm{O}_{5}$ in precambrian iron formations is low, averaging $0.26 \%$ compared to an average of post-cambrian $(0.86 \%)$. The study area is comparable with Precambrian with an average of 0.28 . The content of $\mathrm{MnO}$ is three times greater in Precambrian than the younger iron formations. As compared to 0.009 of $\mathrm{Mn} / \mathrm{Fe}$ ratio for post-cambrian, the study area BIF exactly fits to the Precambrian as it has an average of 0.028 .

The depositional age of Sargur superacrustals must be older than $3400 \mathrm{Ma}^{8}$ as they occur as enclaves within the polyphase trondhuemitic to tonalitic gneisses, whose ages range 
from $2.83 \mathrm{Ga}$ to $3.4 \mathrm{Ga}^{36,37}$. As the BIF of the present area is enclosed by tonalitic gneisses and has been compared geochemically with Sargur BIF in the previous section, it may also be formed in the same age (i.e. $2.83 \mathrm{Ga}$ to $3.4 \mathrm{Ga}$ ).

Chakarborty and Mujumder ${ }^{3}$ and Subba Reddy et.al. ${ }^{38}$ found that the Eu/Sm ratio is very useful particularly in their age. The Eu/Sm ratio for the Precambrian BIF is older than $2500 \mathrm{~m} . \mathrm{y}$. varies from 0.40 to 1.22 ; whereas the values for younger rocks vary from 0.24 to $0.40^{6}$. The Eu/Sm ration of the study area BIF vary from 0.52 to 0.71 , corresponding to Archaean values. In oldest iron formation of Isuva (3800m.y) the average $\mathrm{La} / \mathrm{Lu}$ ratio is 24 with $9-52$ in range. The 1800 m.y. old Ketilidian iron formations show an average $\mathrm{La} / \mathrm{Lu}$ ratio of 94 with the range of $4.0-2.32$. In the study area BIF show $\mathrm{La} / \mathrm{Lu}$ ratio of 23.9 (range $11-43$ ) corresponding to $3800 \mathrm{~m} . y$ approximately.

\section{Conclusion}

The major elements concentration of the study area BIF is compared with various facies and noticed that these are of oxide facies of iron formations. The major, trace and REE concentrations are significantly different from the Algoma, Superior and Proterozoic BIF. Therefore the BIF of the study area has to be treated differently has been given separate type as Tamil Nadu Type. The transport of iron and silica are derived from mantle through hydrothermal solutions and fumarolic activity in submarine conditions and later metamorphosed. Though no direct radiometric age is available for the BIF of this study area, a combination of field and geochemical studies seems to establish that they are of Archaean age. The rare earth elements show close similarities in their concentration and distribution patterns to those in Precambrian BIF in various parts of the world. The Eu/Sm ratio of the study area indicates that the age of these rocks is greater than $2500 \mathrm{M}$.Y and the $\mathrm{La} / \mathrm{Lu}$ ratio conforms that these iron formations are of approximately 3800 M.Y. old.

\section{References}

1. Sarkar S N, Saha A K and Miller J A, Geol Mag., 1977, 106(1), 15-45.

2. Saha A K, Ghosh S, Dasgupta D, Mukhopadhyay K and Ray S L, Indian Soc Earth Sci., 1984, 1-18.

3. Chakraborty K L and Majumder T, J Geol Soc India, 1986, 28, 109-113.

4. Prasad C V R K, Subba Reddy N and Windley B F, J Geol Soc India, 1982, 23, 112-122.

5. Grass G A and Mc Leod C R, Canad Miner., 1980, 181, 223-229.

6. Goel M J and Klein C, J Geol Soc., India, 1981, 89, 169-183.

7. Majunder T, Chakraborty K L and Battacharya A, Mineral Deposita., 1982, 17, 107-118.

8. Apple P W U, Precam Res., 1983, 20, 243-258.

9. Mc Gregor V R and Masan B, Am Miner., 1977, 62, 887-904.

10. Holland D H, Eco Geol., 1973, 68, 1169-1172.

11. Beukes $\mathrm{N}$ and Gutzmer $\mathrm{J}$, Reviews in Economic Geology, Automated Graphic Systems. (Eds., Hagemann S, Rosière C, Gutzmer J and Beukes N J), 2008, 5-47.

12. Mirris, R.C and Horwitz R C, Precam Res., 1983, 21, 273-297.

13. Dalstra H J and Rosierie, Econ Geol., (SEG Reviews), 2008, 15, 73-106.

14. Pirajno F and Bagas L, Precam Res., 2008, 166(1-4), 54-80.

15. Polat A and Frei R, Precambrian Research, 2005, 138(1-2), 151-175.

16. Bavinton O A and Taylor R S, Geochim Cosmochim Acta, 1980, 44, 639-648.

17. Taylor S R and Mc Lennan S M, Phil Trans Royal Soc London, 1981, A-301, 381-399. 
18. Figueiredo E Silva R C, Lobato L M, Rosiere C A, Hagemann S, Zucchetti M, Baars F J, Morais R and Andrade, Econ Geol (SEG Reviews), 2008, 15, 255-290.

19. Subrata Roy and Venkasesh A S, J Earth Syst Sci., 2009, 118(6), 619-641.

20. Manikyamba C, Balaram V and Naqui S M, Precam Res., 1993, 61, 137-164.

21. Khan R M K, Govi P K and Naqui S M, J Geol Soc India, 1992, 40, 311-328.

22. Fryer B J, REE in iron formation. In: Trendal and Mories R C, (Eds.,) Rare Earth elements in iron formations: Facts and Problems, Elsevier. 1983, 345-356.

23. Majunder T, Whitely J E and Chakraborty K L, Chem Geol., 1984, 45, 203-211.

24. Laajoki K, Bull Geol Soc Finland., 1975, 47, 93-107.

25. Dymek R F and Klein C, Precam Res., 1988, 39, 247-302.

26. Devaraju T C and Sadashivaiah M S, J Geol Soc India, 1966, 7, 70-85.

27. Ramberg H, The Origin of Metamorphic and Metasomatic Rocks. Cambridge University Press, Landon, 1952.

28. Turner F J and Verhoogen J, Igneous and metamorphic petrology. Mc Graw-Hill Book Company Inc. New York, 1960.

29. Smit C A, Trans Geol Soc South Afr., 1982, 85(3), 141-153.

30. Windley B F, Simpron P R and Muir M D, Fortsch Miner., 1984, 62(2), 253-267.

31. Gross G A, J Geol Soc India., 1986, 28, 92-108.

32. Jayaram S, Venkatasubramaniam V S and Radhakrishna B P, J Geol Soc India, 1976, 17, 557-561.

33. Crawford A R, J Geol Soc India, 1969, 10, 117-166.

34. Viswanathan S, Geol Mag., 1975, 112, 63-69.

35. Leep H and Goldich S S, Eco Geol., 1964, 59, 1025-1060.

36. Janardhan A S and Vidal Ph., J Geo Soc India, 1982, 23, 578.

37. Beckinsale R D, Drury S A and Holt R W, Nature, 1980, 283, 469-470.

38. Subba Reddy N, Prasad C V R K and Balaram V, J Geo Soc India, 1995, 46, 341-344. 